\title{
New Nesting Records of the Le Conte's Sparrow, Ammospiza leconteii, from Northeastern Ontario, with Some Notes on Nesting Behaviour
}

\author{
Michael PATRikeEv
}

Ontario Parks, 199 Larch Street, Suite 404, Sudbury, Ontario P3E 5P9 Canada

Present address: 3 Helen Street, Dundas, Ontario L9H 1N2 Canada; e-mail: mpatrikeev@ hotmail.com

Patrikeev, Michael. 2006. New nesting records of the Le Conte's Sparrow, Ammospiza leconteii, from northeastern Ontario, with some notes on nesting behaviour. Canadian Field-Naturalist 120(1): 22-26.

Le Conte's Sparrow is sparsely distributed through northeastern Ontario with no confirmed records from Algoma District and eastern Lake Superior. Two nests were found in open poor fen between Wawa and Hawk Junction in central Algoma District in 1999. Notes on behaviour, nests, nestling development and feeding effort were taken during 9 hours and 38 minutes at one nest over three days.

Key Words: Le Conte's Sparrow, Ammospiza leconteii, nesting, northeastern Ontario.

Le Conte's Sparrow (Ammospiza leconteii) is distributed through grasslands and wetlands of central and southern Canada east to Ontario and Quebec, and in the north-central United States. "It is one of the least known North American sparrows and any new information on this species may be of interest" (Lowther 1996). A cryptic species, it nests in thick clumps of dead grass, and its nests are difficult to find. Only about 50 nests had been recorded range-wide by the early 1960s (Walkinshaw 1968) and few have been documented since then (Lowther 1996). Only nine nests of this species had been found in Ontario prior to 1999 (Peck and James 1987; Sandilands and Campbell 1987; G. Peck, personal communication). In Ontario, Le Conte's Sparrow has been reported in widely separated areas in the forest zone with the greatest concentrations in the James Bay Lowland and northwestern Ontario (Sandilands and Campbell 1987). During the first Ontario Breeding Bird Atlas (1981-1985) this species was found in only 20 of 137 UTM blocks $(100 \times 100$ $\mathrm{km}$ ) and nesting was confirmed in only four blocks (Sandilands and Campbell 1987). None of the first Atlas records were from Algoma District, although Le Conte's Sparrow was considered a rare spring species in the vicinity of Wawa (Ontario Ministry of Natural Resources 1990). In 2001-2004, surveyors for the second Ontario Breeding Bird Atlas reported probable nesting in two blocks (Sault Ste. Marie and St. Joseph Island), and possible nesting in five additional blocks in the vicinity of Sault Ste. Marie and Thessalon at the south end of Algoma District (Ontario Breeding Bird Atlas website: http://www.birdsontario.org/atlas).

Here I describe two new nests from central Algoma District, northeastern Ontario. A small group with 2-3 singing males was found in an upland wetland (5.8 ha, $\left.48^{\circ} 02^{\prime} 42.24 \mathrm{~N}^{\prime \prime}, 084^{\circ} 34^{\prime} 01.30 \mathrm{~W} "\right)$ in Esquega Township east of Wawa and southwest of Hawk Junction (Figure 1). The wetland (329 m above sea level) encompassed elements of several wetland types gradually changing from sphagnum bog with few stunted Black Spruce (Picea mariana) to open poor fen and then to a meadow marsh (Harris et al. 1996).

Le Conte's Sparrows inhabited approximately 2 ha of open poor fen in this wetland (see Figure 2). The wetland was bordered by alder thickets (Speckled Alder, Alnus incana) with a few dead Balsam Poplars (Populus balsamifera) and by mixed forest dominated by Trembling Aspen (P. tremuloides) and White Birch (Betula papyrifera). Water regime of the wetland changed from late May through July 1999. The lower parts (mostly meadow marsh section) were flooded in late May (up to $0.5 \mathrm{~m}$ deep), but water gradually receded by late June. The area remained damp, but no standing water remained (natural flow in this wetland was likely disrupted years ago when it was transsected by Highway 101). The area occupied by Le Conte's Sparrows had a ground cover of sphagnum moss and was dominated by two species of sedge: Few-seeded Sedge (Carex oligosperma) and Awl-fruited Sedge ( $C$. stipata); Canada Bluejoint (Calamagrostis canadensis) was also present.

Singing males were heard at the wetland on 21 May 1999, and a display flight observed on 27 May. A flight song is described by Murray (1969). I also observed a "spy flight": a sparrow would rise from the grass and fly in a low arch quickly dropping back into the cover. Le Conte's Sparrow likely uses this flight to determine precise position of an approaching intruder. No song or audible call was uttered during such flight.

Two nests were found in the wetland, on 13 June and 17 July 1999, respectively. The first nest contained five eggs (Figure 3), but was empty on 17 June. The eggs matched a description of Le Conte's Sparrow eggs from Walkinshaw (1968). The second nest contained five newly-hatched young on 17 July and still contained five young on 23 July when the young would be seven days old. On day seven, the young were in cinnamoncoloured plumage with dark streaks on the back, dark 


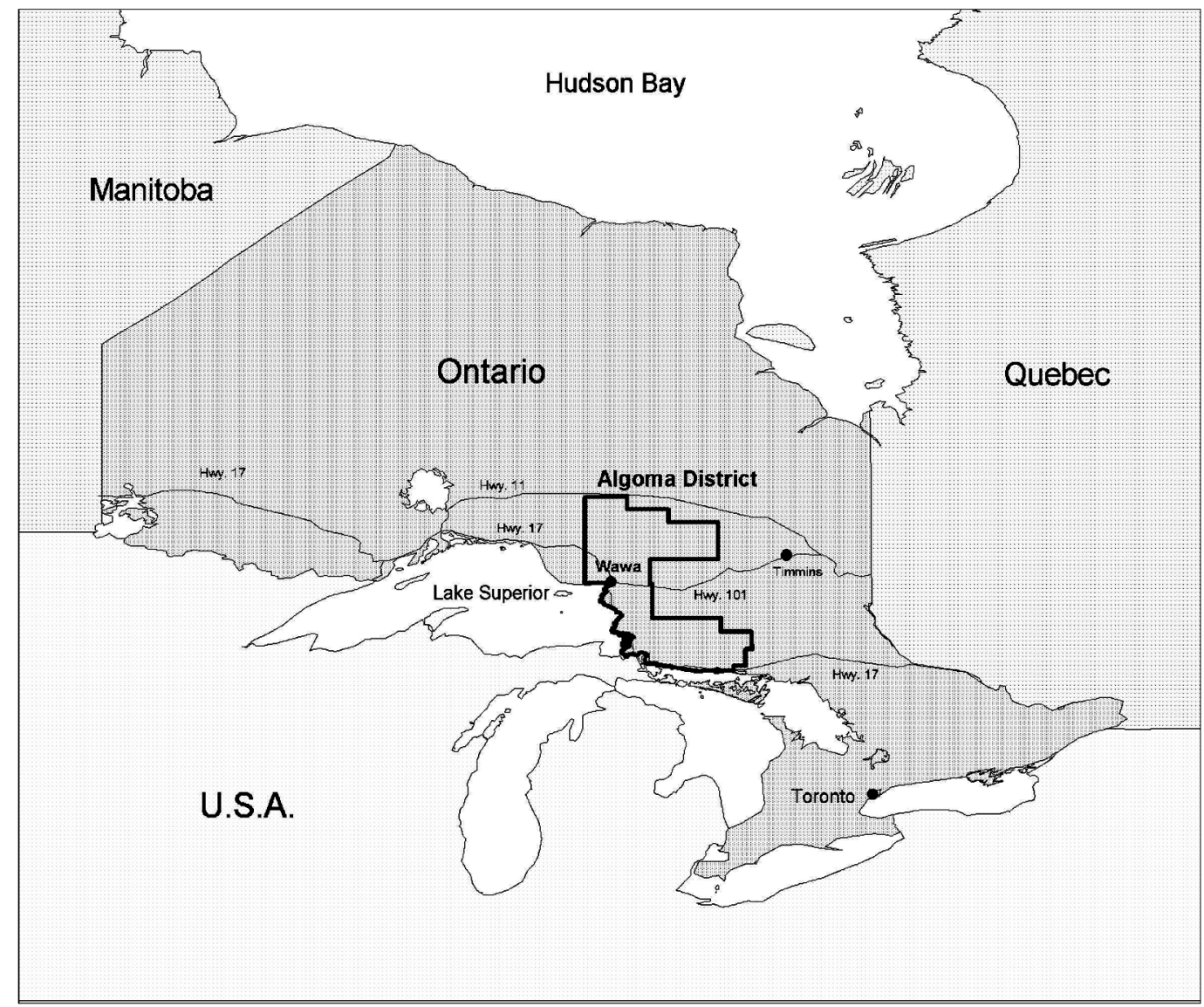

FIgURE 1. Position of Wawa and Algoma District in Ontario.

grey crowns and cheeks, tan median crown-stripe and black shafts. The median crown-stripe was seen in at least some chicks (Figure 4). Bill colour changed from fleshy on days two-three to grey-pink on day seven. Gape was bright flesh red on day seven. According to Gollop et al. (1966), the young leave the nest at the age of seven days.

The two nests were approximately $150 \mathrm{~m}$ apart and might have belonged to the same pair. Both nests were built of dried stems, and lined with fine dried stems of sedge and grass. Outer rim of both nests was loosely built. The first nest was well hidden under and inside a clump of dried graminoids and could not be seen from above. The second nest was attached to dried and living sedge stems and a small Leatherleaf (Chamaedaphne calyculata) under a loose cover of sedges and grasses. Both nests were 5-6 cm above the wet ground.

Observations totaling 9 hours and 38 minutes were made at the second nest from a blind (through a telephoto lens) during late afternoon-early evening hours on 19 July (1610-2045 hours), 21 July (1800-2110) and
22 July (1812-2005). All observations were conducted during calm fair weather. The pair at the nest under observation consisted of a slightly larger brighter male, and a scruffier duller female. Le Conte's Sparrows never flew directly to and from the nest, but landed some distance away and walked (hopped) to it, fed the young and walked away before taking on the wing. Also both birds were never present at the nest at the same time during the observation period. A total of 80 feeding visits was recorded. The birds were bringing food every 6.6 minutes on average ( $\mathrm{SD} \pm 5.2$, Standard error 0.6$)$. Lowther (1996) reported 1 feeding/minute at a nest containing a cowbird. Gender of feeding birds was assumed on 55 occasions. The male fed the young on average every 14.1 minutes $(\mathrm{SD} \pm 13.5)$ and the female every 13.5 minutes $(S D \pm 13.5)$. No differences between sexes were detected in feeding efforts $(P=0.50)$. Intervals between feedings became shorter as the young were growing: every 7.9 minutes \pm 5.9 on 19 July, $5.7 \pm 4.6$ on 21 July and $4.9 \pm 3.0$ on 22 July (KruskalWallis one way ANOVA: $P=0.07$ ). 


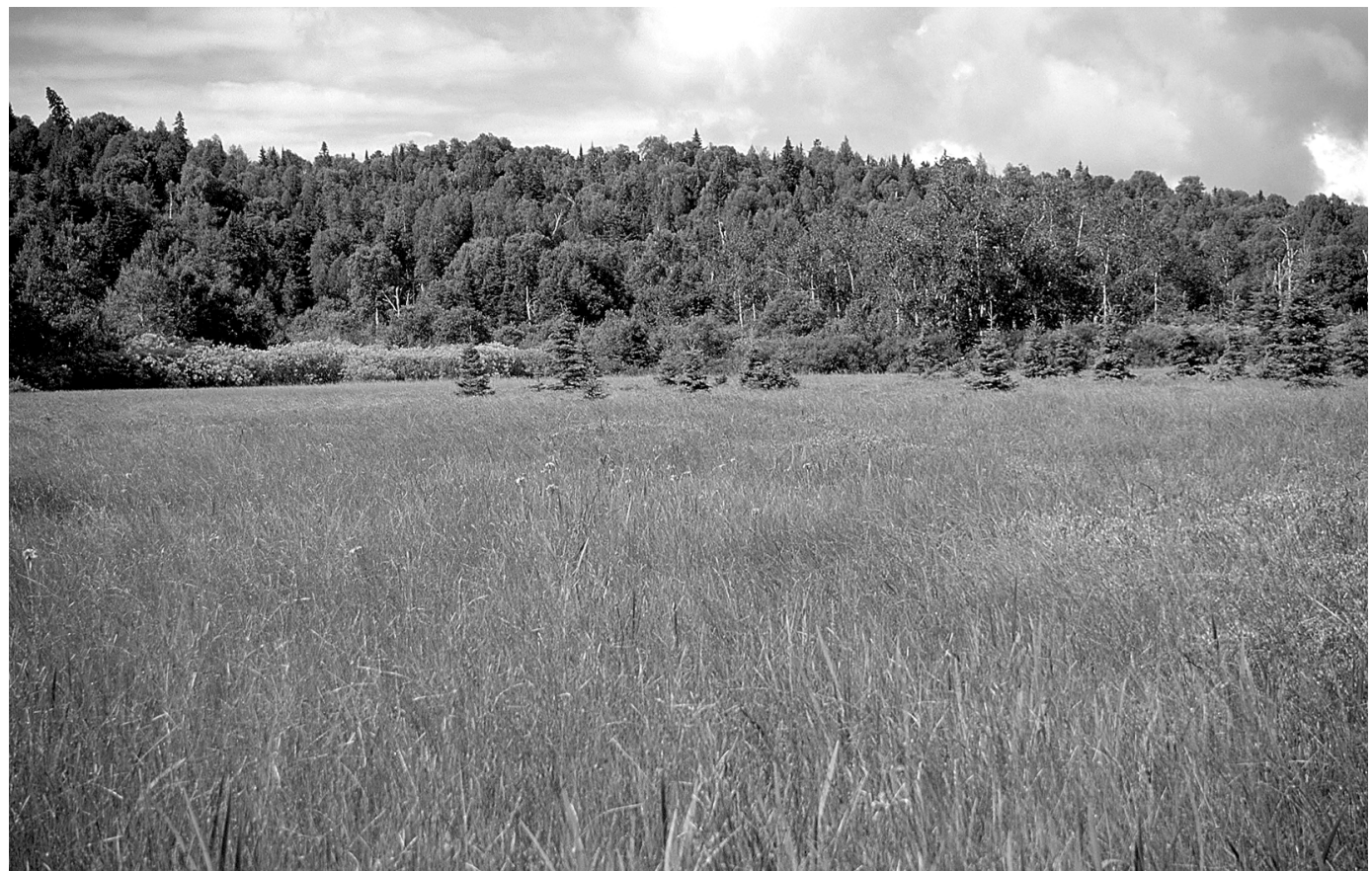

FIGURE 2. Habitat of Le Conte's Sparrow in Esquega Township: this wetland encompassed elements of several wetland types gradually changing from a sphagnum bog to open poor fen and then to a meadow marsh. Le Conte's Sparrows inhabited about 2 ha of open poor fen. Photo by Michael Patrikeev.

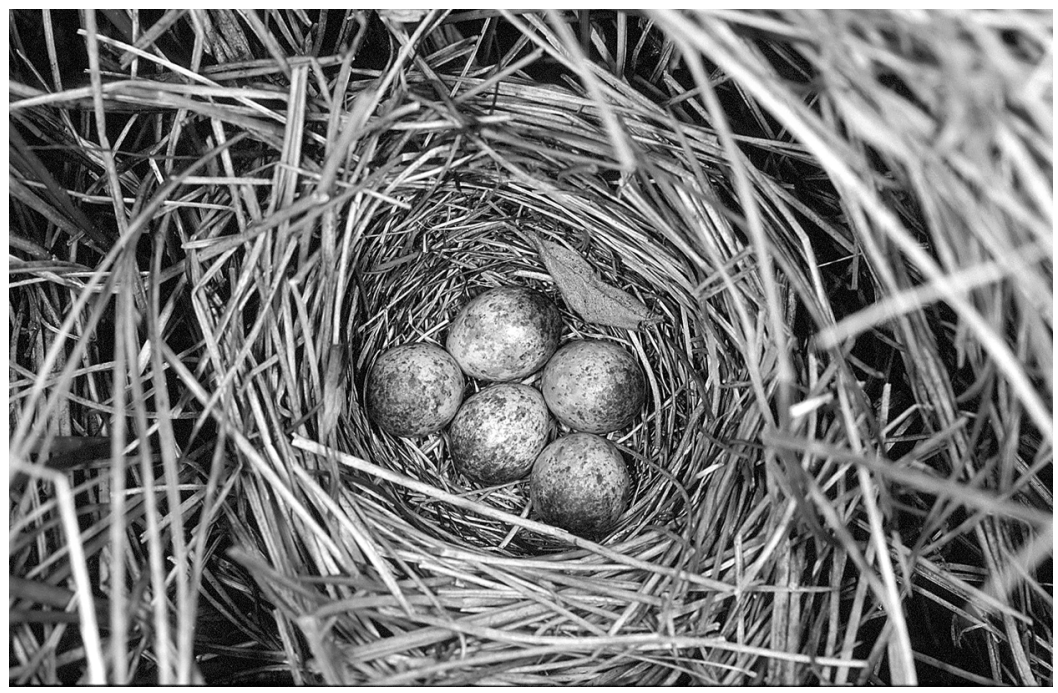

FIgURE 3. Nest of Le Conte's Sparrow with five eggs. The nest was built of dead stems, and lined with fine stems of sedge and grass. It was well hidden under and inside a clump of dead graminoids and could not be seen from above. Photo by Michael Patrikeev. 13 June 1999. 


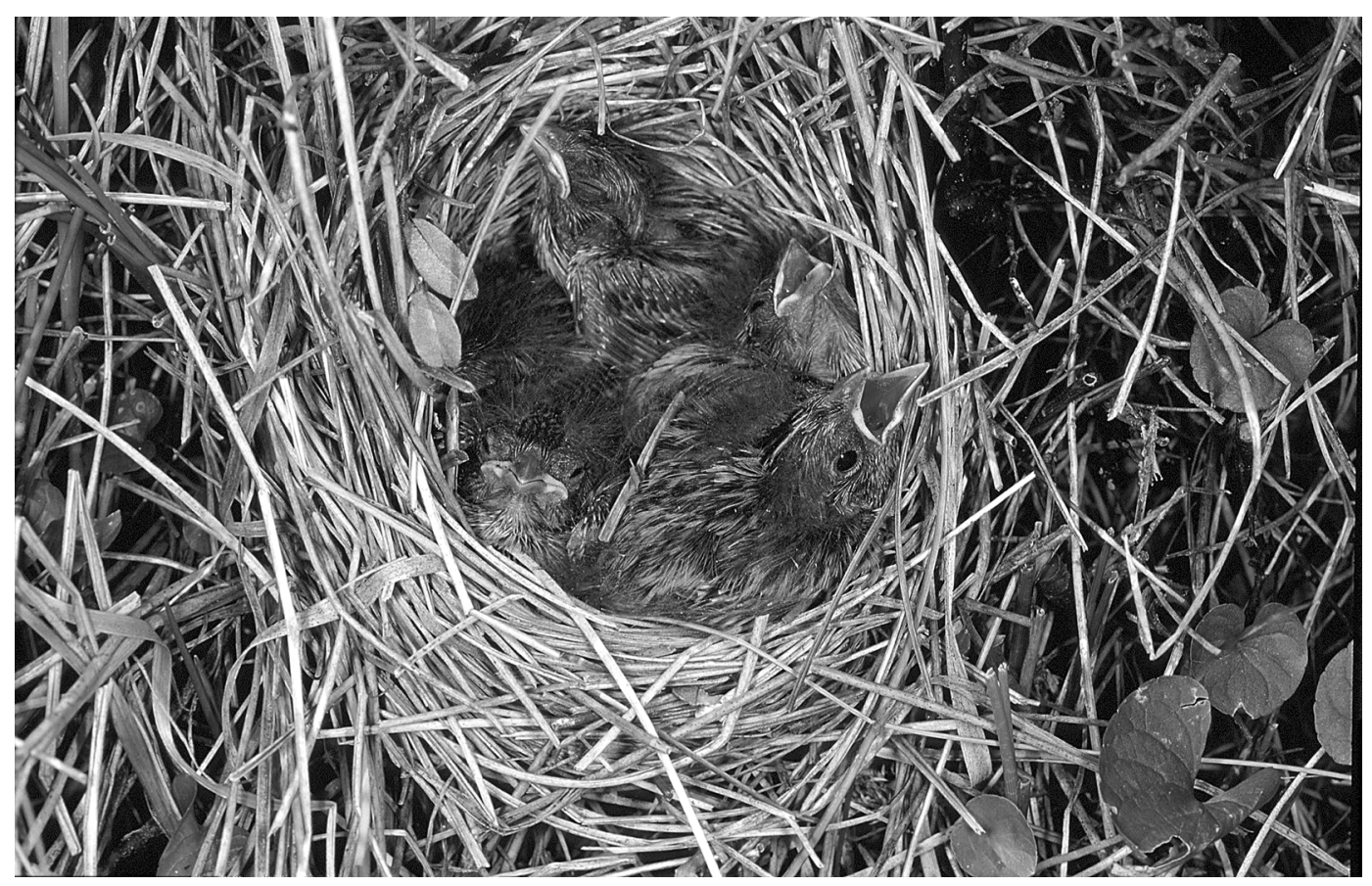

FIgURE 4. Nestlings of Le Conte's Sparrow seven days old. Photo by Michael Patrikeev. 23 July 1999.

Lowther (1996) noted that hardly any information was available on this species' diet. Although in many cases food brought to the young was too small to identify through a telephoto lens, I observed small green caterpillars, a white moth, a spider, a small sphinx caterpillar and two grasshopper abdomens. The last three items were brought by the female who tried to feed them to the small young. The content of the sphinx caterpillar was eventually squeezed into the young's mouths, and one grasshopper abdomen was swallowed by the female itself after futile attempts to feed it to the young.

I did not observe wetlands similar to the one described above in the Wawa area (Michipicoten and Esquega townships, and the adjacent parts of Lake Superior Provincial Park) in 1999-2000 and no Le Conte's Sparrows were detected in other visited wetlands. However, this species likely occurs in low densities throughout Algoma District where suitable habitat is available.

\section{Acknowledgments}

I am grateful to Carol Dersch (Lake Superior Provincial Park) and Kim Taylor (North-Eastern Science and Technology, Ontario Ministry of Natural Resources) for help with plant identification, to George Peck (Royal Ontario Museum) who provided me with information on the number of confirmed nesting records of this species in Ontario, to Richard Knapton (University of Alberta, Edmonton), John C. Eitniear
(San Antonio, Texas), A. J. Erskine and an anonymous reviewer for useful comments on this manuscript.

\section{Literature Cited}

Gollop, J. B., J. A. Slimmon, and R. V. Folker. 1966. Some 1965 bird records for the Saskatoon district. Blue Jay 24: 76-78.

Harris, A. G., S. C. McMurray, P. W. C. Uhlig, J. K. Jeglum, R. F. Foster, and G. D. Racey. 1996. Field guide to the wetland ecosystem classification for northwestern Ontario. Ontario Ministry of Natural Resources, Northwest Science and Technology. Thunder Bay, Ontario. Ontario Field Guide FG-01. 74 pages + Appendices.

Lowther, P. E. 1996. Le Conte's Sparrow (Ammodramus leconteii). In The Birds of North America (224). Edited by A. Poole and F. Gill. The Academy of Natural Sciences, Philadelphia, Pennsylvania, and The American Ornithologists' Union, Washington, D.C.

Murray, B. G., Jr. 1969. A comparative study of Le Conte's and Sharp-tailed sparrows. Auk 86: 199-231.

Ontario Ministry of Natural Resources. 1990. Checklist of Birds/Liste des oiseaux. Lake Superior Provincial Park and adjacent areas/Parc provincial du lac Supérieur et les régions environnantes. Ministry of Natural Resources/Ministère des Richesses naturelles. MNR Number 3752. ISBN 0-7729-6809-8. 24 pages.

Peck, G. K., and R. D. James. 1987. Breeding Birds of Ontario: Nidiology and Distribution. Volume 2: Passerines. Life Sciences Miscellaneous Publication, Royal Ontario Museum, Toronto, Ontario. xi + 387 pages.

Sandilands, A., and C. Campbell. 1987. Le Conte's Sparrow/Bruant de Le Conte Ammodramus leconteii. Pages 
454-455 in Atlas of the Breeding Birds of Ontario. Compiled by M. D. Cadman, P. F. J. Eagles, and F. M. Helleiner. Federation of Ontario Naturalists and Long Point Bird Observatory. University of Waterloo Press.

Walkinshaw, L. H. 1968. Passerherbulus caudacutus (Latham). Le Conte's Sparrow. Pages 765- 776 in Life histories of North American cardinals, grosbeaks, buntings, towhees, finches, sparrows, and allies. Edited by O. L. Austin, Jr. United States National Museum Bulletin 237, Part 2.

Received 21 October 2004

Accepted 14 September 2005 